\title{
Heritability and impact of environmental effects during pregnancy on antral follicle count in cattle
}

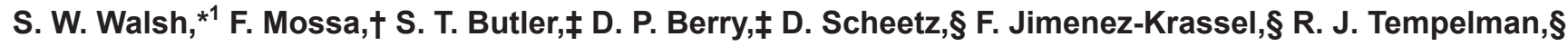 \\ F. Carter,\# P. Lonergan,\# A. C. O. Evans,\# and J. J. Ireland§ \\ *Department of Chemical and Life Sciences, Waterford Institute of Technology, Waterford, Ireland \\ †Università degli Studi di Sassari, Dipartimento di Medicina Veterinaria, Via Vienna, 2, 07100 Sassari, Italy \\ $\ddagger$ Teagasc, Animal and Grassland Research and Innovation Centre, Moorepark, Fermoy, Co. Cork, Ireland \\ §Molecular Reproduction Laboratory, Department of Animal Science, Michigan State University, East Lansing 48824 \\ \#School of Agriculture and Food Science, University College Dublin, Belfield, Dublin 4, Ireland
}

\section{ABSTRACT}

Previous studies have documented that ovarian antral follicle count (AFC) is positively correlated with number of healthy follicles and oocytes in ovaries (ovarian reserve), as well as ovarian function and fertility in cattle. However, environmental factors (e.g., nutrition, steroids) during pregnancy in cattle and sheep can reduce AFC in offspring. The role that genetic and environmental factors play in influencing the variability in $\mathrm{AFC}$ and, correspondingly, the size of the ovarian reserve, ovarian function, and fertility, are, however, poorly understood. The present study tests the hypothesis that variability in AFC in offspring is influenced not only by genetic merit but also by the dam age and lactation status (lactating cows vs. nonlactating heifers) and milk production during pregnancy. Antral follicle count was assessed by ultrasonography in 445 Irish Holstein-Friesian dairy cows and 522 US HolsteinFriesian dairy heifers. Heritability estimates for AFC ( \pm standard error) were $0.31 \pm 0.14$ and $0.25 \pm 0.13$ in dairy cows and heifers, respectively. Association analysis between both genotypic sire data and phenotypic dam data with AFC in their daughters was performed using regression and generalized linear models. Antral follicle count was negatively associated with genetic merit for milk fat concentration. Also, AFC was greater in offspring of dams that were lactating $(\mathrm{n}=255)$ compared with nonlactating dams $(\mathrm{n}=89)$ during pregnancy and was positively associated with dam milk fat concentration and milk fat-to-protein ratio. In conclusion, AFC in dairy cattle is a moderately heritable genetic trait affected by age or lactation status and milk quality but not by level of dam's milk production during pregnancy. Key words: follicle number, environmental impact, maternal environment, heritability

Received November 25, 2013.

Accepted April 5, 2014.

${ }^{1}$ Corresponding author: swalsh@wit.ie

\section{INTRODUCTION}

Due to the influential effects of environmental and management factors, inaccuracy of data recording, and the polygenic and binary nature of most fertility traits routinely used in animal breeding (Patterson et al., 1992; Cammack et al., 2009; Walsh et al., 2011), heritability estimates for most traditional measures of fertility are low and typically less than $5 \%$ in cattle (Pryce and Veerkamp, 2001; Berglund, 2008; Cammack et al., 2009). Nevertheless, the discovery of a moderate to highly heritable phenotype that explains a large proportion of the genetic variation in cow fertility could be very useful to enhance selection of high-fertility females, and also as a juvenile or adult phenotypic marker to identify high-fertility females in herds. For example, during the past several decades, the genetic capacity of dairy cows to produce milk has increased markedly, whereas fertility (as measured by conception rates) has plummeted from around $65 \%$ to 30 to $40 \%$ (Walsh et al., 2011). This implies an antagonistic relationship between genetic merit for milk production and reproduction in dairy cattle (Philipsson, 1981; Lucy, 2001). Thus, discovery of highly heritable phenotypic traits associated with fertility in females is relevant not only to husbandry and reproductive management practices, but also to the development of new breeding schemes for dairy cattle that could ultimately contribute to the future success of the dairy industry.

Antral follicle count (AFC) determined during serial ovarian ultrasonography is defined as the average peak number of follicles $\geq 3 \mathrm{~mm}$ growing during consecutive follicular waves of estrous cycles (Burns et al., 2005). Results from our studies show that AFC is highly variable among cattle (range $=8$ to 56 follicles) but very highly repeatable (repeatability of 0.85 to 0.95 ) within individuals (Burns et al., 2005; Ireland et al., 2007). In addition, the variation in AFC is associated with numerous well-established predictors for fertility in cattle, including total number of morphologically 
healthy follicles and oocytes in ovaries (Ireland et al., 2008), progesterone production during estrous cycles (Jimenez-Krassel et al., 2009), and responsiveness to superovulation and number of transferable embryos (Ireland et al., 2007; Rico et al., 2009). We recently reported that direct measures of fertility, including conception rate and services per conception, were diminished in dairy cows with relatively low follicle numbers compared with higher numbers (Mossa et al., 2012). In addition, a recent study in beef heifers (Snelling et al., 2012) suggested that variation in follicle numbers may be highly heritable $( \pm \mathrm{SE} ; 0.73 \pm 0.18, \mathrm{n}=452)$, whereas studies in women show that age at menopause, which is positively associated with AFC (Faddy and Gosden, 1996), is moderately heritable (range 0.37 to 0.69; Snieder et al., 1998; van Asselt et al., 2004; Murabito et al., 2005; Morris et al., 2011). These preliminary heritability estimates imply that a relatively large portion of the variation in $\mathrm{AFC}$ and associated alterations in ovarian function and fertility may be controlled genetically. However, heritability estimates for AFC have not been documented in dairy cattle.

It is well established that maternal environment during gestation can affect the health of offspring during adulthood (McMillen and Robinson, 2005; Barker, 2007). Relatively few studies, however, have investigated the effects of maternal environment during gestation on fertility of offspring. For example, maternal undernutrition in sheep causes a delay in ovarian follicular development in their offspring (Borwick et al., 1997; Rae et al., 2001), whereas androgen treatment during early gestation in sheep reduces the total number of ovarian follicles and fertility of offspring (Steckler et al., 2005; Smith et al., 2009). More recently, calves born to nutritionally restricted mothers had a $60 \%$ reduction in peak, minimum, and mean AFC during follicle waves compared with calves born to mothers fed control diets (Mossa et al., 2013). Similarly, other studies in cattle reported an effect of maternal nutrition on ovarian measures in their offspring, whereby high levels of protein fed to dams in their second trimester reduced the number of healthy antral follicles in their offspring (Sullivan et al., 2009). Moreover, a previous study in lactating dairy cows has shown that greater maternal milk yield (after adjusting for genetic merit for milk yield) preconception and during gestation was associated with reduced survival, reduced milk yield, and greater SCC in their daughters (Berry et al., 2008). As gestation and lactation are coincident in dairy cows, it is plausible to hypothesize that lactation negatively affects fetal ovarian development, and therefore ovarian function and fertility in their offspring. Deciphering genetic and environmental mechanisms that regulate variability in $\mathrm{AFC}$, and hence the number of healthy follicles and oocytes in ovaries, therefore, could provide useful information for both genetic selection and development of new treatments to enhance fertility in cattle. The objectives of the present study on dairy cattle were to determine (1) whether AFC is heritable; (2) if an association exists between genetic merit for performance and AFC; and (3) whether dam lactation status (lactating versus nonlactating) during gestation and dam milk production variables in lactating dams are associated with their daughter's AFC.

\section{MATERIALS AND METHODS}

Dairy cattle were located at Green Meadow Farms Inc. (Ovid-Elsie, MI) or Teagasc, Moorepark Dairy Production Research Centre (Fermoy, Co. Cork, Ireland). All experiments were performed in compliance with protocols approved by the Institutional Animal Care and Use Committee at Michigan State University (East Lansing) or by the Animal Research Ethics Committee, University College Dublin, the Cruelty to Animal Act (Ireland, 1876), and European Union Directive 86/609/ EC.

\section{Animal Management and AFC Assessment}

United States. In total, 522 Holstein-Friesian dairy heifers (mean \pm SD; 13.9 mo of age \pm 0.76 ) located at Green Meadow Farms Inc. were used in this study. Transrectal ovarian ultrasonography (SSD-900 with a 7.5-MHz linear transducer; Aloka, Tokyo, Japan) was used to determine AFC in each animal by the same operator (Burns et al., 2005). Animals at the appropriate age were moved and housed in 1 of 4 freestall pens in groups of 100 heifers. Every week from September 2008 to February 2009, 25 heifers of approximately 12 to 13 mo of age were synchronized with 2 injections of $\mathrm{PGF}_{2 \alpha}$ (2 mL of cloprostenol, i.m.) given $10 \mathrm{~d}$ apart. Four days after the second $\mathrm{PGF}_{2 \alpha}$ injection, ovaries were scanned to determine AFC.

Ireland. Management of Irish dairy cows in this study has been described previously (Mossa et al., 2012). In summary, a cohort of 445 Irish Holstein-Friesian dairy cows was examined during winter (November-December 2006, $\mathrm{n}=99$, and November-February 2008, $\mathrm{n}=$ 60), summer (July 2011; $\mathrm{n}=44$ ), or spring (April-May 2008 and 2009; $\mathrm{n}=108$ and 134, respectively) on 2 farms at the Teagasc, Moorepark Dairy Production Research Centre in Ireland $\left(55^{\circ} 10^{\prime} \mathrm{N}, 8^{\circ} 16^{\prime} \mathrm{W}\right)$. Transrectal ovarian ultrasonography (SSD-900 with a $7.5-\mathrm{MHz}$ linear transducer; Aloka) was performed by the same operator to determine AFC as previously described (Mossa et al., 2012). Briefly, a single measurement of the total numbers of follicles $\geq 3 \mathrm{~mm}$ in diameter per 
pair of ovaries was recorded for each animal. The Irish dairy cows used in this study did not receive any estrus synchronization treatment. In 2008 and 2009, animals were scanned (approximately $70 \mathrm{~d}$ postpartum) during the first wave of follicular growth of the estrous cycle, approximately $4.6 \pm 1.43$ (mean $\pm \mathrm{SD}$ ) days after estrus. In addition, in winter 2006 and summer 2011, lactating Holstein-Friesian cows were scanned on a random day of the estrous cycle. Individual cow milk yield was recorded daily using electronic milk meters (Dairymaster, Causeway, Co. Kerry, Ireland). Milk samples, collected once weekly from successive morning and evening milkings, were analyzed by using a MilkoScan 203 instrument (Foss Electric, Hillerød, Denmark) to determine milk fat, protein, and lactose concentrations.

Effect of Dam's Lactation Status and Milk Production Variables During Gestation on AFC in Daughters. To determine associations between dam lactation status (whether dam was lactating during gestation) and dam milk production variables during gestation with AFC of their daughters, 2 data sets from Irish cattle were constructed. Of the 445 Irish Holstein-Friesian lactating dairy cows that had an AFC measurement, 273 cows were daughters of lactating dams during gestation, whereas 89 cows were daughters of nulliparous dams (data set 1 ). The second data set (data set 2) was a subset of the first data set and consisted only of cows that were daughters of lactating dams during gestation. Outliers were defined as values $>4$ standard deviations from the mean for individual weekly measurements for milk yield, milk solids yield, and milk fat and protein concentrations. Solids-corrected milk yield was calculated by using the equation of Tyrrell and Reid (1965), incorporating terms for fat, protein, and lactose yields as well as milk volume. Average dam milk fat-to-protein ratio was also calculated because a high fat-to-protein ratio is indicative of negative energy balance (Grieve et al., 1986; Heuer et al., 2000; Friggens et al., 2007; McParland et al., 2011), which could affect fetal ovarian development. Date of conception of offspring was derived from the last recorded AI of the dam. Gestation length records were screened to ensure they were within biological limits. Where dates for the last AI were not available (n $=56$ ), date of conception was calculated using date of birth of female offspring with AFC measurements less a standard gestation length of 282 d (Norman et al., 2009). Following all edits, 8,399 weekly milk production records from 253 dams (representing 255 daughter lactation records) were analyzed for milk fat, protein, and lactose concentrations. Averages for dam weekly milk yield, milk solids yield, milk fat and protein concentrations, and milk fat-to-protein ratio were calculated within 4 periods: $30 \mathrm{~d}$ before conception, d 0 to 90 of gestation, d 91 to 179 of gestation, and d 180 to 282 of gestation.

\section{Estimation of Heritability of AFC}

Phenotypic and genetic variance components for AFC were estimated using an animal linear mixed model in ASReml (Gilmour et al., 2007). The dependent variable was the natural logarithm of AFC and the random effects of animal (i.e., additive genetic effects) were included for both US and Irish models. For US data, the fixed classification effects of day of sample collection as well as the linear effect of age of heifer at collection were included in the model. The pedigree information was traced back 2 generations on each US heifer except for maternal granddams. For Irish data, fixed effects included in the model were lactation number $(1, \mathrm{n}=$ $179 ; 2, \mathrm{n}=91 ; 3, \mathrm{n}=65,4, \mathrm{n}=53 ; \geq 5, \mathrm{n}=57)$ and the contemporary group of year-month of calving. The pedigree of all of the 445 Irish dairy cows was traced back at least 4 generations, where available. The pedigree file consisted of 1,935 nonfounder animals.

\section{Association Between Sire Genetic Performance Traits and Their Daughters' AFC}

To determine the association between genetic merit for milk production, fertility, and health characteristics with AFC, PTA and associated reliabilities for performance traits were extracted from the Irish Cattle Breeding Federation's national genetic evaluation in April 2013 for sires $(n=81)$ of Irish cows that had AFC recorded. Genetic information for performance traits for 13 sires of 34 Irish cows was not recorded in the Irish Cattle Breeding Federation database. A description of models used in Irish genetic evaluations and variance components has been reported previously (Berry et al., 2007). The performance traits of interest included sire PTA for milk yield $(\mathrm{kg})$, milk fat concentration (\%), milk protein concentration (\%), calving interval (d), survival, and geometric mean SCS ( $\log _{e}$ SCC). Sires with less than $70 \%$ reliability for each trait of interest (calving interval $\mathrm{n}=12$; survival, $\mathrm{n}=18$ ) were excluded from the association analysis. The natural logarithm of AFC was individually regressed on the sire PTA separately. The number of cows included in the analysis for milk production traits was 411 , and 399,399 , and 391 cows were included in the analysis of calving interval, survival, and SCS, respectively. Genetic correlations were inferred from the linear regression coefficient, and the ratio of the genetic standard deviation for AFC estimated in this study and the genetic standard deviation of the other performance traits included in the national genetic evaluations (Berry et al., 2007). 
Table 1. Number of cow records (n), coefficients of regression (b; SE in parentheses), their $P$-value, and inferred genetic correlation of the performance traits of the Holstein-Friesian bulls on daughter antral follicle count (natural $\log \mathrm{AFC}$ )

\begin{tabular}{lcrrr}
\hline Parameter & $\mathrm{n}$ & \multicolumn{1}{c}{ b } & \multicolumn{1}{c}{$\begin{array}{c}\text { Genetic } \\
\text { correlation }\end{array}$} \\
\hline PTA milk yield $(\mathrm{kg})$ & 411 & $0.0002(0.0002)$ & 0.24 & 0.37 \\
PTA fat concentration (\%) & 411 & $-0.3859(0.1937)$ & 0.05 & -0.53 \\
PTA protein concentration (\%) & 411 & $-0.6191(0.4186)$ & 0.14 & -0.43 \\
PTA calving interval (d) & 399 & $0.0059(0.0079)$ & 0.46 & 0.20 \\
PTA survival (\%) & 399 & $-0.0031(0.0127)$ & 0.81 & -0.05 \\
PTA SCC (cells/mL) & 391 & $-0.4301(0.2700)$ & 0.11 & -0.33 \\
\hline
\end{tabular}

\section{Dam Lactation Status and Milk Production Variables During Gestation}

To determine the association between daughter AFC (dependent variable) of Irish lactating cows and dam lactation status during gestation (i.e., lactating vs. nonlactating; data set 1), regression analysis (PROC GLM; SAS Institute, 2011) was performed. The statistical model included the categorical variables lactation status during gestation, parity, and week of the year in which AFC assessment of the cow (daughter) took place.

To determine the association between daughter AFC (dependent variable) and dam phenotypic performance (independent variable) for milk yield, fat and protein percentages, SCM yield, and milk fat-to-protein ratio, linear regression (PROC GLM) analysis using SAS was performed within each period. Each independent variable was analyzed separately. For all models, fixed effects adjusted for in the model were, where significant $(P<0.05)$, month of calving, year of calving, and week of the year in which AFC assessment of the cow (daughter) took place. Parity of dam in the year she conceived and parity of daughter in the year she was scanned were also included in the model because parity is known to influence AFC (Mossa et al., 2012).

\section{RESULTS}

The mean AFC $( \pm \mathrm{SD})$ in US dairy heifers was $16.2 \pm$ $7.8(\mathrm{n}=522)$, ranging from 2 to 51 follicles per heifer. The heritability for AFC $( \pm \mathrm{SE})$ in US dairy heifers was $0.25 \pm 0.13$. The genetic standard deviation and coefficient of genetic variation were $0.24 \log _{\mathrm{e}}$ follicles and $9.2 \%$, respectively. The mean AFC $( \pm \mathrm{SD})$ in Irish dairy cows was $18.7 \pm 9.0$, ranging from 4 to 55 follicles per cow. The heritability $( \pm \mathrm{SE})$ for AFC in Irish dairy cows was $0.31 \pm 0.14$. The genetic standard deviation and coefficient of genetic variation were $0.26 \log _{\mathrm{e}}$ follicles and $9 \%$, respectively.

A negative $(P<0.05)$ linear relationship was evident between sire PTA for milk fat concentration and AFC, with AFC decreasing by 0.4 per 1-percentage-unit increase in fat concentration (Table 1). The inferred genetic correlation was -0.53 .

Lactation status (whether dam was lactating during gestation) was associated $(P<0.01)$ with $\mathrm{AFC}$ in their daughters. Daughters of nonlactating dams (heifers) during gestation had $3.3 \pm 1.2(\mathrm{AFC} \pm \mathrm{SE})$ fewer follicles than daughters of lactating dams (mean $\pm \mathrm{SE}$; $15.9 \pm 1$ vs. $19.2 \pm 0.6 ; P<0.01)$.

Summary statistics for dam milk production performance before conception and during each trimester of pregnancy in Irish lactating dairy cows are outlined in Table 2. Associations between dam milk production in the period before conception or during gestation and AFC in their daughters are detailed in Table 3. We found no association between dam milk yield, protein concentration, and SCM yield with AFC in their offspring. However, dam milk fat concentration in the first 2 trimesters and dam fat-to-protein ratio in all 3 trimesters were positively associated with daughter $\operatorname{AFC}(P<0.05)$.

\section{DISCUSSION}

The most significant findings of the present study were that (1) AFC was moderately heritable (between 0.25 and 0.31 ) in dairy cattle; (2) a negative association existed between PTA for milk fat concentration with AFC, (3) AFC was greater in daughters of lactating cows compared with daughters of nonlactating heifers, and (4) a positive association existed between both milk fat concentration and fat-to-protein ratio during most trimesters of pregnancy in dams with AFC in daughters. Typically, heritability estimates for traditional measures of fertility traits are less than 5\% (Pryce and Veerkamp, 2001). The finding in our study that AFC was moderately heritable in dairy cattle is significant, because cattle with relatively low AFC have several phenotypic characteristics typically associated with poor fertility (Ireland et al., 2007; Cushman et al., 2009; Jimenez-Krassel et al., 2009). For example, recent studies in beef heifers and dairy cows report an almost $10 \%$ 
Table 2. Number of dam records (n), mean, and standard deviation for dam milk production before conception and during each trimester of pregnancy

\begin{tabular}{|c|c|c|c|c|}
\hline Time period & Trait & $\mathrm{n}$ & Mean & $\mathrm{SD}$ \\
\hline Before conception & Milk yield (kg) & 253 & 196.1 & 45.71 \\
\hline \multirow[t]{4}{*}{$(\mathrm{d}-30$ to $\mathrm{d}-1)$} & Fat concentration $(\%)$ & 253 & 3.9 & 0.54 \\
\hline & Protein concentration (\%) & 253 & 3.3 & 0.24 \\
\hline & Milk solids yield & 253 & 183.0 & 40.92 \\
\hline & Fat:protein ratio & 253 & 1.2 & 0.16 \\
\hline First trimester & Milk yield (kg) & 251 & 163.9 & 36.83 \\
\hline \multirow[t]{4}{*}{$(\mathrm{d} 0$ to $\mathrm{d} 89)$} & Fat concentration $(\%)$ & 251 & 3.9 & 0.44 \\
\hline & Protein concentration (\%) & 251 & 3.4 & 0.23 \\
\hline & Milk solids yield & 251 & 152.1 & 31.85 \\
\hline & Fat:protein ratio & 251 & 1.2 & 0.12 \\
\hline Second trimester & Milk yield (kg) & 246 & 118.4 & 27.30 \\
\hline \multirow[t]{4}{*}{ (d 90 to $d 179)$} & Fat concentration $(\%)$ & 246 & 4.3 & 0.51 \\
\hline & Protein concentration (\%) & 246 & 3.7 & 0.29 \\
\hline & Milk solids yield & 246 & 117.2 & 25.79 \\
\hline & Fat:protein ratio & 246 & 1.2 & 0.11 \\
\hline Third trimester & Milk yield (kg) & 214 & 72.4 & 24.58 \\
\hline \multirow[t]{4}{*}{ (d 90 to $d 282)$} & Fat concentration $(\%)$ & 214 & 4.6 & 0.60 \\
\hline & Protein concentration (\%) & 214 & 3.9 & 0.41 \\
\hline & Milk solids yield & 214 & 74.8 & 24.64 \\
\hline & Fat:protein ratio & 214 & 1.2 & 0.12 \\
\hline
\end{tabular}

difference in overall pregnancy rate between animals with low ( $\leq 15$ follicles $\geq 3 \mathrm{~mm}$ in diameter) compared with a higher AFC (Cushman et al., 2009; Mossa et al., 2012). Furthermore, our results clearly indicate that a significant portion of the variability in $\mathrm{AFC}$ in our sample of Irish and US Holstein-Friesian populations is regulated genetically. In support of this finding, others report that the number of oocytes collected by ovum pick-up, which we have shown is positively associated with AFC in cattle (Ireland et al., 2008), has a moderate heritability of 0.25 in cattle (Merton et al., 2009), whereas AFC in beef cattle has a heritability of 0.73 (Snelling et al., 2012). Antral follicle count during follicular waves is not only a highly repeatable phenotypic trait positively associated with ovary size, number of morphologically healthy oocytes, ovarian function, and

Table 3. Intercept, coefficients of regression (b), and $P$-values based on regression analysis for daughter antral follicle count and maternal milk production variables within $30 \mathrm{~d}$ before conception and first, second, and third trimesters of pregnancy

\begin{tabular}{|c|c|c|}
\hline Item & $\mathrm{b}( \pm \mathrm{SE})$ & $P$-value ${ }^{1}$ \\
\hline \multicolumn{3}{|l|}{$30 \mathrm{~d}$ before conception } \\
\hline Milk yield (kg) & $0.000(0.001)$ & 0.79 \\
\hline Fat concentration $(\%)$ & $0.060(0.062)$ & 0.33 \\
\hline Protein concentration (\%) & $-0.100(0.158)$ & 0.53 \\
\hline Fat:protein ratio & $0.271(0.209)$ & 0.20 \\
\hline SCM yield (kg) & $0.001(0.001)$ & 0.56 \\
\hline \multicolumn{3}{|l|}{ First trimester } \\
\hline Milk yield (kg) & $0.000(0.001)$ & 0.86 \\
\hline Fat concentration (\%) & $0.184(0.077)$ & 0.02 \\
\hline Protein concentration (\%) & $0.133(0.156)$ & 0.40 \\
\hline Fat:protein ratio & $0.665(0.312)$ & 0.04 \\
\hline SCM yield (kg) & $0.001(0.001)$ & 0.50 \\
\hline \multicolumn{3}{|l|}{ Second trimester } \\
\hline Milk yield (kg) & $-0.001(0.001)$ & 0.37 \\
\hline Fat concentration $(\%)$ & $0.158(0.069)$ & 0.02 \\
\hline Protein concentration (\%) & $0.025(0.132)$ & 0.85 \\
\hline Fat:protein ratio & $0.843(0.318)$ & 0.009 \\
\hline SCM yield (kg) & $-0.001(0.002)$ & 0.73 \\
\hline \multicolumn{3}{|l|}{ Third trimester } \\
\hline Milk yield $(\mathrm{kg})$ & $-0.002(0.002)$ & 0.14 \\
\hline Fat concentration (\%) & $0.097(0.066)$ & 0.14 \\
\hline Protein concentration (\%) & $-0.039(0.104)$ & 0.71 \\
\hline Fat:protein ratio & $0.739(0.336)$ & 0.03 \\
\hline SCM yield (kg) & $-0.002(0.002)$ & 0.26 \\
\hline
\end{tabular}

${ }^{1}$ Significance of maternal milk production on daughter antral follicle count. 
fertility in cattle (Burns et al., 2005; Ireland et al., 2007, 2008; Cushman et al., 2009; Mossa et al., 2010, 2012) but also a moderately heritable genetic trait, as shown in the present study. However, collection of AFC data for genetic evaluations is not economically feasible because of limitations on the numbers of animals that can be processed ultrasonographically in a day and by the age and size of the calf at the time at which transrectal ultrasonography can occur. Thus, more easily measurable markers predictive of AFC and associated traits, such as anti-Müllerian hormone (AMH), which is highly positively associated with AFC in cattle (Ireland et al., 2008, 2011), may be a more useful predictor of fertility. Nonetheless, ultrasonographic examinations of reproductive tracts are routinely performed on some farms in Ireland before the start of the breeding season and this not only provides an opportunity for AFC assessment but may also contribute to reproductive management decisions. However, in a recent study, follicle numbers were not different between Irish lactating cows with high and low genetic merit for fertility, despite differences in ovarian dynamics during the estrous cycle (Cummins et al., 2012). This suggests that selection for high genetic merit for fertility may not increase AFC. However, a relatively small number of animals were used and precise AFC during follicular waves (Burns et al., 2005) was not determined in that study, thus the relationship between genetic merit for fertility and AFC remains uncertain.

This study examined for the first time the association between AFC and genetic merit for performance traits. Milk yield was not genetically correlated with AFC, implying that selection for milk yield does not adversely affect AFC. Interestingly, a negative genetic association between milk fat concentration and AFC in daughters was observed. Although the decrease in AFC was small, there may, however, be a greater loss in the number of microscopic follicles (primordial, primary, secondary, and tertiary follicles) in the ovarian reserve because a positive association exists between relatively small follicles and AFC (Cushman et al., 2000; Ireland et al., 2008). This suggests that genetic alterations in milk fat could adversely affect AFC and the size of the ovarian reserve. This is likely due to the positive association between milk fat concentration and negative energy balance as outlined in the following paragraph.

The rationale to evaluate milk fat concentration and milk fat-to-protein ratio was due to reported associations with energy balance, health, and fertility traits (Heuer et al., 2000; Friggens et al., 2007; Buttchereit et al., 2010; McParland et al., 2011; Toni et al., 2011; Negussie et al., 2013), all of which could affect fetal ovarian development. In early lactation, a critical period defined by negative energy balance, pronounced changes in milk fat-to-protein ratio are observed because of increased lipolysis, which results in increased fat percentage. Concurrently, inadequate intake of fermentable carbohydrates leads to reduced protein synthesis by ruminal bacteria, resulting in reduced protein. In the early postpartum period, a high fat-toprotein ratio, indicative of negative energy balance, has been associated with increased risk of disease, lameness, mastitis, ovarian abnormalities, poor reproductive performance, and culling (Heuer et al., 1999; Toni et al., 2011; Negussie et al., 2013). However, weak correlations between these traits and milk fat-to-protein ratio are observed as lactation progresses, presumably as cows exit the negative energy balance phase (McParland et al., 2011; Toni et al., 2011; Negussie et al., 2013). Therefore, during early lactation, milk fat-to-protein ratio may be a valuable indicator trait for energy balance that has consequences for reproductive performance of the dam but also perhaps for her developing fetus, including its lifetime AFC.

In our study, nulliparous heifers not lactating during gestation produced daughters that had fewer AFC than daughters of cows lactating during gestation. In addition, although dam milk production before conception and during pregnancy was not associated with daughter AFC, a positive association between dam milk fat and milk fat-to-protein ratio during gestation and daughter AFC was observed. Therefore, we also speculate that the associations of daughter AFC with dam age or lactation status and with milk quality are mediated by the same factors for 2 reasons. First, lactation not only modifies the metabolic (insulin, IGF-I, NEFA, BHBA, glucose) and endocrine (estradiol, progesterone, prolactin, oxytocin) milieu but is also associated with reduced fertility, which is more pronounced in older compared with younger animals (Walsh et al., 2011). In our study, despite age differences between dams (mean age $\pm \mathrm{SD}$; nulliparous heifers, $2.03 \pm 0.19$; lactating cows, $4.7 \pm 1.7$; mean parity $\pm \mathrm{SD}, 2.6 \pm 1.6$ ), the finding that daughters of nulliparous heifers had fewer follicles compared with daughters of lactating dams seems counterintuitive because metabolic stress is greater in lactating compared with nonlactating cows (Rizos et al., 2010; Maillo et al., 2012). A possible explanation for this could include the likelihood that heifers with low AFC have lower fertility than those with higher AFC and, as such, low AFC animal do not get pregnant and progress to contribute data to the lactating animal group. Although it appears that daughter AFC increases with dam age or lactation, this is unlikely to be the case. It is possible that this observation could be due increased survivability of high-AFC animals in the herd, for reasons previously mentioned, and as AFC is heritable, the $\mathrm{AFC}$ in offspring of high-AFC animals 
increases with dam age or lactation, as these animals remain in the herd longer. Alternatively, perhaps nutrients are preferentially partitioned toward growth in heifers (Scholl et al., 1994; Wallace et al., 2006; Redmer et al., 2009), which could limit fetal follicle development without compromising fetal growth, as in our previous study in cattle (Mossa et al., 2013). It is likely that the altered metabolic and hormonal environment induced by lactation mediates effects on fetal folliculogenesis as studies in sheep indicate that the ovarian reserve is negatively affected by the maternal hormonal environment (Steckler et al., 2005; Smith et al., 2009). For example, prenatal testosterone treatment from d 30 to 90 of gestation causes a significant reduction in total number of follicles on d 140 of gestation and at 10 mo of age (Steckler et al., 2005; Smith et al., 2009). Little is known about the effects of nutrition during lactation on fetal folliculogenesis; however, rats exposed to malnutrition during lactation showed reduced primordial follicle numbers at puberty (da Silva Faria et al., 2010) and reduced pregnancy rates at 1 yr of age (Guzmán et al., 2006). Based on that research, some of our findings may seem counterintuitive (that AFC was higher in daughters from multiparous lactating cows and that a positive association existed between daughter AFC and dam fat and fat-to-protein ratio in milk) because current knowledge indicates that metabolic stress is more severe in cows with high milk fat concentration and milk fat-to-protein ratio. However, this result may be confounded by the fact that both AFC and milk fat concentration are influenced by parity, with lower AFC and milk fat concentrations observed in first-parity animals compared with other parities (Cushman et al., 2009; Mossa et al., 2012; Yang et al., 2013). Therefore, a direct comparison of daughters of lactating and nonlactating age-matched animals will be necessary to partially answer this question.

Second, not only does nutrition plays a large role in altering milk fat concentration (Palmquist et al., 1993), but phenotypic associations between dam nutritional strategies and ovarian follicle development in offspring have been reported in cattle (Sullivan et al., 2009; Mossa et al., 2013). For example, calves born to nutritionally restricted beef heifer dams have $60 \%$ lower AFC during follicle waves compared with calves born to beef heifer dams fed control diets (Mossa et al., 2013). In sheep, modifications to maternal diets lead to poor fetal growth concomitant with suppression of gonadotropin gene expression in the pituitary and reduction of the number of follicles in ovaries of late-gestation lambs (Da Silva et al., 2002) and a delay in fetal ovarian development (Borwick et al., 1997). Perhaps, physiological and metabolic perturbations associated with energy partitioning or induced by lactation influence gonadal development and hence could affect subsequent fertility. However, the mechanisms whereby lactation and nutrition of dams alter AFC and the ovarian reserve in their daughters are unclear.

\section{CONCLUSIONS}

This study has demonstrated, for the first time, that AFC is heritable in dairy cattle and has a greater heritability than most other traditional measures of fertility. Additionally, results from this study link milk fat concentration both genetically and phenotypically with AFC in offspring. Finally, AFC in offspring is influenced by dam age or lactation status and also milk quality, although it is not affected by dam milk yield.

\section{ACKNOWLEDGMENTS}

The financial support of the research stimulus fund (RSF-06-328) is gratefully acknowledged. The authors thank J. P. Murphy, J. Kenneally, A. Brennan, and the staff at Teagasc, Moorepark Animal and Grassland Research and Innovation Centre for their care and management of the experimental animals and also A. Geoghegan for technical support (Teagasc Moorepark).

\section{REFERENCES}

Barker, D. J. 2007. The origins of the developmental origins theory. J. Intern. Med. 261:412-417.

Berglund, B. 2008. Genetic improvement of dairy cow reproductive performance. Reprod. Domest. Anim. 43(Suppl. 2):89-95.

Berry, D. P., P. Lonergan, S. T. Butler, A. R. Cromie, T. Fair, F. Mossa, and A. C. Evans. 2008. Negative influence of high maternal milk production before and after conception on offspring survival and milk production in dairy cattle. J. Dairy Sci. 91:329-337.

Berry, D. P., L. Shalloo, A. R. Cromie, R. F. Veerkamp, P. Dillon, P. R. Amer, J. F. Kearney, R. D. Evans, and B. Wickham. 2007. The economic breeding index: A generation on. Pages 29-34 in Tech. Rep. to the Irish Cattle Breeding Federation. Accessed Jan. 12, 2012. http://www.icbf.com/publications/files/economic_ breeding_index.pdf.

Borwick, S. C., S. M. Rhind, S. R. McMillen, and P. A. Racey. 1997. Effect of undernutrition of ewes from the time of mating on fetal ovarian development in mid gestation. Reprod. Fertil. Dev. 9:711-715.

Burns, D. S., F. Jimenez-Krassel, J. L. Ireland, P. G. Knight, and J. J. Ireland. 2005. Numbers of antral follicles during follicular waves in cattle: Evidence for high variation among animals, very high repeatability in individuals, and an inverse association with serum follicle-stimulating hormone concentrations. Biol. Reprod. 73:54-62.

Buttchereit, N., E. Stamer, W. Junge, and G. Thaller. 2010. Evaluation of five lactation curve models fitted for fat:protein ratio of milk and daily energy balance. J. Dairy Sci. 93:1702-1712.

Cammack, K. M., M. G. Thomas, and R. M. Enns. 2009. Review: Reproductive traits and their heritabilities in beef cattle. Prof. Anim. Sci. 25:517-528.

Cummins, S. B., P. Lonergan, A. C. Evans, and S. T. Butler. 2012. Genetic merit for fertility traits in Holstein cows: II. Ovarian follicular and corpus luteum dynamics, reproductive hormones, and estrus behavior. J. Dairy Sci. 95:3698-3710. 
Cushman, R. A., M. F. Allan, L. A. Kuehn, W. M. Snelling, A. S. Cupp, and H. C. Freetly. 2009. Evaluation of antral follicle count and ovarian morphology in crossbred beef cows: Investigation of influence of stage of the estrous cycle, age, and birth weight. J. Anim. Sci. 87:1971-1980.

Cushman, R. A., V. S. Hedgpeth, S. E. Echternkamp, and J. H. Britt. 2000. Evaluation of numbers of microscopic and macroscopic follicles in cattle selected for twinning. J. Anim. Sci. 78:1564-1567.

Da Silva, P., R. P. Aitken, S. M. Rhind, P. A. Racey, and J. M. Wallace. 2002. Impact of maternal nutrition during pregnancy on pituitary gonadotropin gene expression and ovarian development in growth-restricted and normally grown late gestation sheep fetuses. Reproduction 123:769-777.

da Silva Faria, T., F. de Bittencourt Brasil, F. J. Sampaio, and C. da Fonte Ramos. 2010. Maternal malnutrition during lactation affects folliculogenesis, gonadotropins, and leptin receptors in adult rats. Nutrition 26:1000-1007.

Faddy, M. J., and R. G. Gosden. 1996. A model conforming the decline in follicle numbers to the age of menopause in women. Hum. Reprod. 11:1484-1486.

Friggens, N. C., C. Ridder, and P. Lovendahl. 2007. On the use of milk composition measures to predict the energy balance of dairy cows. J. Dairy Sci. 90:5453-5467.

Gilmour, A. R., B. R. Cullis, S. J. Welham, and R. Thompson. 2007. ASREML Reference Manual. New South Wales Agriculture, Orange Agricultural Institute, Orange, NSW, Australia.

Grieve, D. G., S. Korver, Y. S. Rijpkema, and G. Hof. 1986. Relationship between milk composition and some nutritional parameters in early lactation. Livest. Prod. Sci. 14:239-254.

Guzmán, C., R. Cabrera, M. Cardenas, F. Larrea, P. W. Nathanielsz, and E. Zambrano. 2006. Protein restriction during fetal and neonatal development in the rat alters reproductive function and accelerates reproductive ageing in female progeny. J. Physiol. $572: 97-108$.

Heuer, C., Y. H. Schukken, and P. Dobbelaar. 1999. Postpartum body condition score and results from the first test day milk as predictors of disease, fertility, yield, and culling in commercial dairy herds. J. Dairy Sci. 82:295-304.

Heuer, C., W. M. Van Straalen, Y. H. Schukken, A. Dirkzwager, and J. P. T. M. Noordhuizen. 2000. Prediction of energy balance in a high yielding dairy herd in early lactation: model development and precision. Livest. Prod. Sci. 65:91-105.

Ireland, J. J., G. W. Smith, D. Scheetz, F. Jimenez-Krassel, J. K. Folger, J. L. H. Ireland, F. Mossa, P. Lonergan, and A. C. O. Evans. 2011. Does size matter in females? An overview of the impact of the high variation in the ovarian reserve on ovarian function and fertility, utility of anti-Mullerian hormone as a diagnostic marker for fertility and causes of variation in the ovarian reserve in cattle. Reprod. Fertil. Dev. 23:1-14.

Ireland, J. J., F. Ward, F. Jimenez-Krassel, J. L. Ireland, G. W. Smith, P. Lonergan, and A. C. Evans. 2007. Follicle numbers are highly repeatable within individual animals but are inversely correlated with FSH concentrations and the proportion of goodquality embryos after ovarian stimulation in cattle. Hum. Reprod. 22:1687-1695.

Ireland, J. L., D. Scheetz, F. Jimenez-Krassel, A. P. Themmen, F. Ward, P. Lonergan, G. W. Smith, G. I. Perez, A. C. Evans, and J. J. Ireland. 2008. Antral follicle count reliably predicts number of morphologically healthy oocytes and follicles in ovaries of young adult cattle. Biol. Reprod. 79:1219-1225.

Jimenez-Krassel, F., J. K. Folger, J. L. Ireland, G. W. Smith, X. Hou, J. S. Davis, P. Lonergan, A. C. Evans, and J. J. Ireland. 2009. Evidence that high variation in ovarian reserves of healthy young adults has a negative impact on the corpus luteum and endometrium during estrous cycles in cattle. Biol. Reprod. 80:1272-1281.

Lucy, M. C. 2001. Reproductive loss in high-producing dairy cattle: Where will it end? J. Dairy Sci. 84:1277-1293.

Maillo, V., D. Rizos, U. Besenfelder, V. Havlicek, A. K. Kelly, M. Garrett, and P. Lonergan. 2012. Influence of lactation on metabolic characteristics and embryo development in postpartum Holstein dairy cows. J. Dairy Sci. 95:3865-3876.
McMillen, I. C., and J. S. Robinson. 2005. Developmental origins of the metabolic syndrome: Prediction, plasticity, and programming. Physiol. Rev. 85:571-633.

McParland, S., G. Banos, E. Wall, M. P. Coffey, H. Soyeurt, R. F. Veerkamp, and D. P. Berry. 2011. The use of mid-infrared spectrometry to predict body energy status of Holstein cows. J. Dairy Sci. 94:3651-3661.

Merton, J. S., B. Ask, D. C. Onkundi, E. Mullaart, B. Colenbrander, and M. Nielen. 2009. Genetic parameters for oocyte number and embryo production within a bovine ovum pick-up-in vitro production embryo-production program. Theriogenology 72:885-893.

Morris, D. H., M. E. Jones, M. J. Schoemaker, A. Ashworth, and A. J. Swerdlow. 2011. Familial concordance for age at natural menopause: Results from the Breakthrough Generations Study. Menopause 18:956-961.

Mossa, F., F. Carter, S. W. Walsh, D. A. Kenny, G. W. Smith, J. L. Ireland, T. B. Hildebrandt, P. Lonergan, J. J. Ireland, and A. C. Evans. 2013. Maternal undernutrition in cows impairs ovarian and cardiovascular systems in their offspring. Biol. Reprod. 88:92. http://dx.doi.org/10.1095/biolreprod.112.107235.

Mossa, F., F. Jimenez-Krassel, J. K. Folger, J. L. Ireland, G. W. Smith, P. Lonergan, A. C. Evans, and J. J. Ireland. 2010. Evidence that high variation in antral follicle count during follicular waves is linked to alterations in ovarian androgen production in cattle. Reproduction 140:713-720.

Mossa, F., S. W. Walsh, S. T. Butler, D. P. Berry, F. Carter, P. Lonergan, G. W. Smith, J. J. Ireland, and A. C. Evans. 2012. Low numbers of ovarian follicles $\geq 3 \mathrm{~mm}$ in diameter are associated with poor fertility in dairy cows. J. Dairy Sci. 95:2355-2361.

Murabito, J. M., Q. Yang, C. Fox, P. W. Wilson, and L. A. Cupples. 2005. Heritability of age at natural menopause in the Framingham Heart Study. J. Clin. Endocrinol. Metab. 90:3427-3430.

Negussie, E., I. Stranden, and E. A. Mantysaari. 2013. Genetic associations of test-day fat:protein ratio with milk yield, fertility, and udder health traits in Nordic Red cattle. J. Dairy Sci. 96:1237-1250.

Norman, H. D., J. R. Wright, M. T. Kuhn, S. M. Hubbard, J. B. Cole, and P. M. VanRaden. 2009. Genetic and environmental factors that affect gestation length in dairy cattle. J. Dairy Sci. 92:2259-2269

Palmquist, D. L., A. D. Beaulieu, and D. M. Barbano. 1993. Feed and animal factors influencing milk fat composition. J. Dairy Sci. 76:1753-1771.

Patterson, D. J., R. C. Perry, G. H. Kiracofe, R. A. Bellows, R. B. Staigmiller, and L. R. Corah. 1992. Management considerations in heifer development and puberty. J. Anim. Sci. 70:4018-4035.

Philipsson, J. 1981. Genetic aspects of female fertility in dairy cattle. Livest. Prod. Sci. 8:307-319.

Pryce, J. E., and R. F. Veerkamp. 2001. The incorporation of fertility indices in genetic improvement programmes. Pages $237-249$ in Fertility in the high producing dairy cow. Vol. 26. M. G. Diskin, ed. Br. Soc. Anim. Sci. Occ. Publ., Edinburgh, UK.

Rae, M. T., S. Palassio, C. E. Kyle, A. N. Brooks, R. G. Lea, D. W Miller, and S. M. Rhind. 2001. Effect of maternal undernutrition during pregnancy on early ovarian development and subsequent follicular development in sheep fetuses. Reproduction 122:915922.

Redmer, D. A., J. S. Luther, J. S. Milne, R. P. Aitken, M. L. Johnson, P. P. Borowicz, M. A. Borowicz, L. P. Reynolds, and J. M. Wallace. 2009. Fetoplacental growth and vascular development in overnourished adolescent sheep at day 50, 90 and 130 of gestation. Reproduction 137:749-757.

Rico, C., S. Fabre, C. Medigue, N. di Clemente, F. Clement, M. Bontoux, J. L. Touze, M. Dupont, E. Briant, B. Remy, J. F. Beckers, and D. Monniaux. 2009. Anti-müllerian hormone is an endocrine marker of ovarian gonadotropin-responsive follicles and can help to predict superovulatory responses in the cow. Biol. Reprod. 80:50-59.

Rizos, D., F. Carter, U. Besenfelder, V. Havlicek, and P. Lonergan. 2010. Contribution of the female reproductive tract to low fertility in postpartum lactating dairy cows. J. Dairy Sci. 93:1022-1029. 
SAS Institute. 2011. User's Guide. Version 9.1.0 ed. SAS Institute Inc., Cary, NC.

Scholl, T. O., M. L. Hediger, J. I. Schall, C. S. Khoo, and R. L. Fischer. 1994. Maternal growth during pregnancy and the competition for nutrients. Am. J. Clin. Nutr. 60:183-188.

Smith, P., T. L. Steckler, A. Veiga-Lopez, and V. Padmanabhan. 2009. Developmental programming: differential effects of prenatal testosterone and dihydrotestosterone on follicular recruitment, depletion of follicular reserve, and ovarian morphology in sheep. Biol. Reprod. 80:726-736.

Snelling, W. M., R. A. Cushman, M. R. Fortes, A. Reverter, G. L. Bennett, J. W. Keele, L. A. Kuehn, T. G. McDaneld, R. M. Thallman, and M. G. Thomas. 2012. Physiology and Endocrinology Symposium: How single nucleotide polymorphism chips will advance our knowledge of factors controlling puberty and aid in selecting replacement beef females. J. Anim. Sci. 90:1152-1165.

Snieder, H., A. J. MacGregor, and T. D. Spector. 1998. Genes control the cessation of a woman's reproductive life: A twin study of hysterectomy and age at menopause. J. Clin. Endocrinol. Metab. $83: 1875-1880$.

Steckler, T., J. Wang, F. F. Bartol, S. K. Roy, and V. Padmanabhan. 2005. Fetal programming: Prenatal testosterone treatment causes intrauterine growth retardation, reduces ovarian reserve and increases ovarian follicular recruitment. Endocrinology 146:31853193.
Sullivan, T. M., G. C. Micke, R. M. Greer, H. F. Irving-Rodgers, R. J. Rodgers, and V. E. Perry. 2009. Dietary manipulation of Bos indicus $\times$ heifers during gestation affects the reproductive development of their heifer calves. Reprod. Fertil. Dev. 21:773-784.

Toni, F., L. Vincenti, L. Grigoletto, A. Ricci, and Y. H. Schukken. 2011. Early lactation ratio of fat and protein percentage in milk is associated with health, milk production, and survival. J. Dairy Sci. 94:1772-1783.

Tyrrell, H. F., and J. T. Reid. 1965. Prediction of the energy value of cow's milk. J. Dairy Sci. 48:1215-1223.

van Asselt, K. M., H. S. Kok, P. L. Pearson, J. S. Dubas, P. H. Peeters, E. R. Te Velde, and P. A. van Noord. 2004. Heritability of menopausal age in mothers and daughters. Fertil. Steril. 82:1348-1351.

Wallace, J. M., J. S. Luther, J. S. Milne, R. P. Aitken, D. A. Redmer, L. P. Reynolds, and W. W. Hay Jr. 2006. Nutritional modulation of adolescent pregnancy outcome-A review. Placenta 27(Suppl. A):S61-68

Walsh, S. W., E. J. Williams, and A. C. O. Evans. 2011. A review of the causes of poor fertility in high milk producing dairy cows. Anim. Reprod. Sci. 123:127-138.

Yang, L., Q. Yang, M. Yi, Z. H. Pang, and B. H. Xiong. 2013. Effects of seasonal change and parity on raw milk composition and related indices in Chinese Holstein cows in northern China. J. Dairy Sci. 96:6863-6869. 